\title{
Accelerated wound healing phenotype in Interleukin 12/23 deficient mice
}

\author{
Marie AT Matias ${ }^{1,2^{*}}$, Jodi M Saunus ${ }^{2}$, Saso Ivanovski ${ }^{3}$, Laurence J Walsh ${ }^{1}$ and Camile S Farah ${ }^{1,2}$
}

\begin{abstract}
Background: The concept that a strong inflammatory response involving the full complement of cytokines and other mediators is critical for unimpaired healing has been challenged by wound healing studies using transgenic and knockout (KO) mice. The present study explored the effect of abrogation of the p40 subunit, which is shared by the pro-inflammatory cytokines interleukin (IL)-12 and IL-23, on wound closure of excisional oral mucosal wounds.

Methods: Double IL-12 and IL-23 KO mice and C57BL / 6J wildtype mice were wounded on the dorsal surface of the tongue using a $2 \mathrm{~mm}$ biopsy punch. The degree of epithelialization was examined histologically. At specific timepoints wounds were examined for cellular and molecular markers for inflammation and angiogenesis using 1) immunohistochemistry; 2) analysis of RNA expression; and 3) flow cytometric analysis.

Results: Compared to wild type controls, $\mathrm{KO}$ mice displayed enhanced healing, which was driven by a greater influx of neutrophils and macrophages during the early stages of wound healing, and increased induction of messenger RNA (mRNA) for endothelial derived neutrophil attractant (ENA78) chemokine and macrophage inflammatory protein-2 alpha (MIP-2 $\alpha$ ). Increased mRNA for monocyte-attracting chemokines including monocyte chemoattractant protein (MCP)-1 and MCP-3 was seen from day 1, together with higher levels of IL-1 $\beta$ and IL-6 within 24 hours after wounding. In addition, mRNA for vascular endothelial growth factor (VEGF)-A was upregulated in $\mathrm{KO}$ mice within 2 hours after injury, and higher expression of this mediator was confirmed by immunohistochemistry.
\end{abstract}

Conclusion: Overall, the accelerated oral mucosal wound healing seen in IL-12/IL-23p40 KO compared to wildtype mice was associated with the early establishment of an inflammatory response and vascularization.

Keywords: Wound healing, Interleukin-12, Interleukin-23, p40, Inflammation, Angiogenesis

\section{Background}

A wound undergoes three distinct stages which overlap in time as it heals: inflammation, proliferation and remodeling/tissue maturation. The characteristics of the inflammatory response define the progress of a healing wound. For example, diabetic ulcers and chronic pressure ulcers are associated with persistent inflammation [1], while keloids or scar formation is rarely seen in fetal wounds which show a diminished inflammatory response [2]. Studies using transgenic and knockout (KO) mice shed significant light on the cellular and molecular mechanisms in wound healing. For example, PU.1-knockout mice which are

\footnotetext{
* Correspondence: m.matias@uq.edu.au

${ }^{1}$ University of Queensland, School of Dentistry, Brisbane, Australia

Full list of author information is available at the end of the article
}

deficient in neutrophils and macrophages show slightly enhanced rates of re-epithelialization, enhanced angiogenesis, and an absence of fibrosis [3], with phagocytosis being undertaken by fibroblasts. A cluster of genes expressed after wounding has been linked with tissue repair genes, and another with inflammation and its consequences. The former provides the basic repertoire to allow normal healing to occur, even in the absence of professional phagocytes [4]. This gene cluster concept cast doubts on the dogma that inflammation is mandatory for repair after injury.

Wound healing studies in cytokine $\mathrm{KO}$ mice have shown that both pro- and anti- inflammatory cytokines influence the healing process. While IL-6 KO mice [5] and IL-1 receptor antagonist (IL-1ra) KO mice [6] show
C Biomed Central

(C) 2011 Matias et al; licensee BioMed Central Ltd. This is an Open Access article distributed under the terms of the Creative Commons Attribution License (http://creativecommons.org/licenses/by/2.0), which permits unrestricted use, distribution, and reproduction in any medium, provided the original work is properly cited. 
slower healing, mice which are deficient in TNF receptor p55 [7] or IFN- $\gamma$ show accelerated healing, most likely by augmenting TGF- $\beta 1$ mediated signalling pathways [8]. A recent study of wound healing in IL-10 KO mice also showed accelerated wound healing [9]. IL-10 down-regulates several pro-inflammatory cytokines including IL-1, IL-6, IL-12, IFN- $\gamma$ and TNF- $\alpha$. IL-10 mice show accelerated re-epithelialization as well as greater macrophage infiltration and enhanced wound contraction compared to wild-type controls [9].

Dissecting the process of wound healing using other well established cytokine KO mice such as IL12/IL-23p40 is of interest because it is shared by two inflammatory cytokines, interleukin-12 (IL-12) and interleukin-23 (IL23). IL-12/IL-23p40 is produced primarily by activated inflammatory cells such as macrophages, neutrophils and dendritic cells as well as by keratinocytes and respiratory epithelial cells [10-12]. The effects of IL-12 and IL-23 are related but distinct. IL-12 promotes differentiation of CD4+ naïve $\mathrm{T}$ cells to $\mathrm{TH}_{1}$ effector cells which stimulate natural killer $(\mathrm{NK})$ cells and $\mathrm{CD} 8+\mathrm{T}$ cells to produce IFN- $\gamma$ [11]. In contrast, IL-23 stimulation of naïve CD4+ $\mathrm{T}$ cells in conjunction with IL- $1 \beta$ gives rise to $\mathrm{TH}_{17}$ cells, which secrete multiple cytokines including IL-17A, IL$17 \mathrm{~F}, \mathrm{IL}-22$, IL-26, IFN- $\gamma$, IL- 6 and TNF- $\alpha$. There is also evidence that the IL-23-17A axis is important in early mucosal immune responses [13].

A potential role for IL-12 and IL-23 in wound healing is suggested by IL-12 having anti- angiogenic activity which is mediated through its effects on promoting secretion of IFN- $\gamma$ [14], which in turn increases production of IFN- $\gamma$-inducible protein 10 (IP-10) a potent inhibitor of angiogenesis which prevents formation of new blood vessels [15-17]. The IL-12/IL-23p40 molecule itself appears to be a natural antagonist to IL-12, competitively binding to the IL- $12 \beta 1$ receptor $[18,19]$. The molecule also serves as a chemoattractant for macrophages [20] and it promotes migration of activated dendritic cells [21]. Blockade of IL-12/IL-23p40 through its effects on IL-23 may also influence wound healing by up-regulation of MMP-9 which has downstream effects on angiogenesis [22]. Despite the above work, the basic question of whether inflammation is beneficial or a hindrance in the wound repair process remains, and use of $\mathrm{p} 40 \mathrm{KO}$ mice may provide further insight into this. The present study uses an oral mucosal wound healing model based on excisional tongue biopsies which follows wound healing events as in the skin.

This study is the first to report that abrogation of the IL-12/IL-23p40 molecule results in accelerated reepithelialization of wounds, and reveals that IL-12 and IL-23 influence wound healing by modulating early inflammatory responses and subsequent angiogenesis.

\section{Methods}

Animals

Specific pathogen-free female $I L-12 / I L-23 p 40^{-/-}$mice and their respective $\mathrm{C} 57 \mathrm{BL} / 6 \mathrm{~J}$ controls $6-8$ weeks of age were used in these experiments. $I L-12 / I L-23 p 40^{-/-}$mice raised on C57BL/6J background [23] were obtained from the Monash Institute of Reproduction and Development, Monash University Melbourne Australia. Mice were bred at Herston Medical Research Centre, Brisbane, Australia, with regular polymerase chain reaction (PCR) based genotyping. Mice were housed in filter-top cages in a PC2 facility, and provided food and water ad libitum. Animal experiments were approved by the Animal Experimentation Ethics Committee of the University of Queensland, and carried out in accordance with the National Health and Medical Research Council's Australian Code of Practice for the Care and Use of Animals for Scientific Purposes, 1997.

\section{Wound healing model}

Under light general anesthesia, a wound was created using a standard $2 \mathrm{~mm}$ diameter punch biopsy positioned along the dorsal mid-line of the tongue, $3 \mathrm{~mm}$ from its anterior tip. Animals were sacrificed at specific timepoints for: 1) immunohistochemistry; 2) analysis of RNA expression; and 3) flow cytometric analysis. In all cases, a $4 \mathrm{~mm}$ punch biopsy was used to harvest the wound site so that the wound was removed in toto. For analysis of RNA expression, harvested wounds were stored immediately in RNAlater $^{\circledR}$ (Ambion, Applied Biosystems, Austin, TX, USA) and kept at $-80^{\circ} \mathrm{C}$. Samples harvested for histology were fixed in $4 \%$ paraformaldehyde in phosphate-buffered saline (PBS) for a minimum of 2 days, then bisected and embedded in paraffin. Serial sections from the central portion of the wounds were used for histological analysis. For flow cytometric analysis, tissues were placed into RPMI 1640 medium (Invitrogen; Mulgrave, VIC, Australia) containing antibiotics/antimycotics ( $\mathrm{Ab} / \mathrm{Am}$; Gibco ${ }^{\circledR}$-Invitrogen, Mulgrave, VIC, Australia) and processed immediately.

\section{Histology}

For each strain of mice and for each time point, 10 mice were wounded and wounds were harvested on day 0 (unwounded) and at 1, 4, 7 and 10 days after wounding. Serial sections from the central portion of the wound were stained with haematoxylin and eosin, and the extent of wound closure determined. A wound was defined as completely healed/closed when all central serial sections demonstrated an intact superficial epithelial layer over the wound area.

\section{Histochemistry}

Harvested wounds $\left(\mathrm{n}=3\right.$ ) from $I L-12 / I L-23 p 40^{-/-}$mice and $\mathrm{C} 57 \mathrm{BL} / 6 \mathrm{~J}$ controls were collected at day zero and at 
1, 4 and 7 days after wounding. Serial sections from the central wound area were used for analysis. Antigen retrieval from the fixed tissues was undertaken using microwave treatment in $0.01 \mathrm{M}$ sodium citrate buffer. Prior to the first layer reagent, sections were treated with Peroxidazed 1 (Biocare Medical, LLC; Concord, $C A$ ) for 10 minutes to block endogenous peroxidise activity, and then incubated with normal donkey serum (5\%) for 20 minutes to stop non-specific binding. The first layer anti-mouse antibodies were applied at predetermined optimal dilutions overnight. Markers for neutrophils ( $A b D$, Serotec, Oxford, UK), macrophages (M3/84) (BD Pharmingen, Franklin Lakes, NJ, USA), CD31 (Santa Cruz Biotechnology, Santa Cruz, CA, USA) and Factor VIII related antigen (Zymed Laboratories, San Francisco, CA) were used. The secondary antibody (SuperPicture Broad Spectrum, Invitrogen, Mulgrave, $V I C$, Australia) was then applied and incubated for 1 hour. For visualization, the Vector NovaRed Substrate Kit (Vector Laboratories, Burlingame, CA) was used. Sections were counterstained with haematoxylin prior to mounting. For Factor VIII staining, trypsin digestion (Zymed Digest-All, Zymed Laboratories Inc., San Francisco, US) was performed for 1 hour at room temperature before applying the primary antibody. The slides were then scanned using Aperio Scanner (Aperio, California, USA) and the digital slides stored for analysis. For each specimen, equivalent fields were examined on serial sections, thus enabling comparisons to be made between markers. In all cases, localization was assessed both qualitatively and quantitatively. The number of neutrophils and macrophages was calculated as number of positive cells counted in 10 high-power fields ( $\times 400$ magnification) divided by 10 [24,42]. Anti-CD31 antibody was used to localize areas of angiogenesis. This antibody stains cell surfaces of monocytes, neutrophils, platelets and endothelial cells, and has been used frequently as a marker of angiogenesis in a number of wound healing studies $[7,9,25,26]$. Using Aperio ImageScope v10 software area for CD31 and Factor VIII staining was measured. As previously described, CD31 positive areas within the wound bed were measured and the percent vascularization was calculated as: \% CD31+ve area $=($ CD $31+$ ve area $/$ Total wound bed area) $\times 100 \%$ [25]. Anti-Factor VIII, a marker which is specific for endothelial cells, megakaryocytes and platelets was used to confirm areas of angiogenesis. The area of Factor VIII staining was calculated as \% Factor VIII (Angiogenesis) $=$ (Factor VIII+ve area/Total wound bed area) $\times 100 \%$.

\section{Analysis of RNA expression}

RNA was isolated from 2 mice per strain $(I L-12 / I L$ $23 p 40^{-/-}$mice and $\left.\mathrm{C} 57 \mathrm{BL} / 6 \mathrm{~J}\right)$ at four timepoints: day 0 (unwounded), 2 hours, 1 day and 4 days after wounding, from the $4 \mathrm{~mm}$ biopsies using TRIZOL (Invitrogen, $\mathrm{Mul}$ grave, VIC, Australia) according to the manufacturer's instructions. To prevent amplification from genomic DNA templates, total RNA was DNAse- treated using DNA-free ${ }^{\mathrm{TM}}$ (Ambion, Applied Biosystems, Austin, TX, $U S A)$ according to the manufacturer's instructions. RNA concentration was determined by spectrophotometry using the NanoDrop ${ }^{\circledR}$ ND-1000 (Thermo Scientific, Washington, USA), and the ratio of absorbance at 260 $\mathrm{nm}$ and $280 \mathrm{~nm}$ was used to assess the purity of the sample. To check RNA integrity, total RNA was electrophoresed in $1.2 \%$ agarose gel. $28 \mathrm{~S}$ and $18 \mathrm{~S}$ rRNA served as markers for RNA integrity.

cDNA was prepared using the "Superscript III" kit (Invitrogen, Mulgrave, VIC, Australia) using random hexamers (Promega, Alexandria, NSW, Australia) from $3 \mu \mathrm{g}$ of total RNA according to the manufacturer's instructions. mRNA for 84 genes involved in inflammation and immunity including IL-1B, IL-6, MCP-1, MCP2, Cxcl2 (MIP-2) and Cxcl5 (Ena-78) was quantified in triplicate using the SuperArray $\mathrm{RT}^{2}$ Profiler ${ }^{\mathrm{TM}} \mathrm{PCR}$ Array (PAMM-073E) (SABioscience, Frederick, MD, USA). Fold changes in expression of the genes of interest (GOI) between samples were calculated using the software provided by the array manufacturer. The average of housekeeping genes (HKG) including glucoronidase $\beta-1$ (Gusb), hypoxanthine guanine phosporibosyl tranferase 1 (Hprt1), heat shock protein $90 \mathrm{kDa} \alpha$ class B member 1 (Hprt1), glyceraldehyde-3-phosphate dehydrogenase (Gapdh) and Actin- $\beta 1$ (Actb) was used. The change in $C_{t}$ value was calculated as: $\Delta C_{t}=C_{t}^{G O I}-C_{t}^{A V G ~ H K G}$. The change for each gene across two groups was calculated as: $\Delta \Delta C_{t}=C_{t}$ (group 1) $-C_{t}$ (group2) where group 1 was the control and group 2 the experimental group.

Following this, the fold-change for each gene from group 1 to group 2 was calculated as $2\left(-\Delta \Delta C_{t}\right)$ with $p$ value of 0.05 .

VEGF- $\alpha$ mRNA and the loading control $18 \mathrm{~S}$ ribosomal RNA (rRNA) were quantified on a 7900 Sequence Detection System in triplicate using SDS 2.2.3 software (Applied Biosystems, Mulgrave, VIC, Australia). Reactions contained SYBR green PCR master mix (Applied Biosystems, Mulgrave, VIC, Australia), VEGF- $\alpha$ primer (F-cacgacagaaggagagcaga, R-aagatgtccaccagggtctc, $100 \mathrm{nM}$ ) and $18 \mathrm{~S}$ (F-catttggagggcaagtctgg, R-tcccaagatccaactacgagc, $100 \mathrm{nM}$ ) and the template diluted appropriately in distilled water. Cycling conditions were $10 \mathrm{~min} @ 95^{\circ} \mathrm{C}$, followed by 45 cycles of $15 \mathrm{sec} @ 95^{\circ} \mathrm{C}$ and $1 \mathrm{~min} @ 59^{\circ} \mathrm{C}$. Complementary DNA synthesis reactions conducted with no reverse transcriptase were included to control for genomic DNA contamination. Post-PCR melt analysis was conducted to ensure that the quantified PCR products were pure and 
free of non-specific amplicons. The comparative $\Delta \Delta \mathrm{C}_{\mathrm{t}}$ method (Applied Biosystems, Mulgrave, VIC, Australia) was used to determine cytokine mRNA expression relative to $18 \mathrm{~S}$ rRNA, relative to unwounded wildtype. Fold changes were calculated as mentioned above.

\section{Flow cytometry}

Six tissue samples were harvested and pooled for each of $I L-12 / I L-23 p 40^{-/-}$and C57BL/6J mice for the following timepoints: day 0 (unwounded), 2 hours, 1 day, 4 days and 7 days after wounding. Tissues were homogenized and a single cell suspension prepared for flow cytometry analysis as described previously [13]. Briefly, tissues were placed in digestion medium [RPMI-1640 (Invitrogen, Mulgrave, VIC, Australia), 5\% fetal calf serum (FCS) (Gibco ${ }^{\circledR}$-Invitrogen, Invitrogen, Mulgrave, VIC, Australia), Ab/Am (Gibco ${ }^{\circledR}$-Invitrogen, Mulgrave, VIC, Australia), monensin (eBioscience; San Diego, CA), collagenase 1A (2 mg/mL; Sigma-Aldrich; Castle Hill, $N S W$, Australia) and hyaluronidase $\left(100 \mathrm{U} \mathrm{mL}^{-1}\right.$; Sigma; Castle Hill, NSW, Australia)] after being minced finely using a scalpel blade. The samples were incubated in digestion medium for 1.5 hours at $37^{\circ} \mathrm{C}$ in a shaking water bath. Homogenates were then filtered through a metal filter $(250 \mu \mathrm{m})$ and the residue resuspended in Cell-free Dissociation buffer (Life Technologies, Invitrogen, Mulgrave, VIC, Australia). The collected single cell suspension was then diluted in RPMI-1640 containing $5 \%$ FCS, and cells then washed by centrifugation at 400 $g$ for $3 \mathrm{~min}$ at $4^{\circ} \mathrm{C}$. Cells were then resuspended in staining buffer [Flow Cytometry Staining Buffer (eBioscience; San Diego, CA), containing 2\% FCS (Gibco ${ }^{\circledR}$-Invitrogen, Mulgrave, VIC, Australia)] to a final concentration of 4 $\times 10^{7}$ cells $/ \mathrm{mL}$.

For each immunofluorescence reaction, $2 \times 10^{6}$ cells were incubated in $50 \mu \mathrm{l}$ blocking buffer $[1 \mu \mathrm{g}$ anti$\mathrm{CD} 16 / 32$ in $50 \mu \mathrm{lL}$ of staining buffer] for 10 minutes on ice prior to incubation with monoclonal antibodies $(\mathrm{mAb})$ at pre-optimized dilutions as follows: fluorescein isothiocyanate-conjugated (FITC) anti-F4/80 $\mathrm{mAb}$ (macrophages) $\left(1 \mu \mathrm{g}\right.$ per $2 \times 10^{6}$ cells, (eBioscience; San Diego, $C A$ ), phycoerythrin (PE) conjugated anti-neutrophil mAb $\left(20 \mu \mathrm{l}\right.$ per $2 \times 10^{6}$ cells, MCA771PE; Abd Serotec, Raleigh, NC) and allophycocyanin (APC) conjugated anti-CD31 mAb $\left(1 \mu \mathrm{g}\right.$ per $2 \times 10^{6}$ cells, (eBioscience; San Diego, CA), for 30 minutes in the dark at $4^{\circ} \mathrm{C}$. Samples were washed three times by centrifugation in PBS at $400 \mathrm{~g}$ for 5 minutes at $4^{\circ} \mathrm{C}$, then the cells resuspended in Cell Dissociation Buffer (Life Technologies, Invitrogen, Invitrogen, Mulgrave, VIC, Australia) for flow cytometric analysis within 2 hours using an LSRII flow cytometer (Becton Dickinson, North Ryde, Australia). Data collection was based on at least 10,000 events. Data were analyzed using FACSDiva software (V6.0; Becton Dickinson,
North Ryde, Australia). Gates were established using unstained control samples including a 1:1 mixture of cells from C57BL/6J mice and $I L-12 / I L-23 p 40^{-/-}$mice.

\section{Statistical Analysis}

To test the null hypothesis that there was no difference between healing in test and control mice, the log-rank (Mantel-Cox) test was used. Differences in gene expression and in histological markers (inflammatory infiltrate, vascularity and granulation tissue) were assessed using the $t$ - test.

\section{Results}

Accelerated rate of oral mucosal wound healing in IL-12 and IL-23 deficient mice

Histological analysis of healing wounds in $I L-12 / I L-$ $23 p 40^{-/}$and $\mathrm{C} 57 \mathrm{BL} / 6 \mathrm{~J}$ showed an accelerated healing pattern in the KO mice compared to WT mice (Log-rank test, $p=0.002$; Table 1 ), based on 10 mice (1 wound per mice) from each group examined at 4 and 7 days after injury. Wound closure was defined as complete re-epithelialization from all central sections of a wound. All wounds from both strains of mice showed partial epithelial coverage at 1 day after wounding. At 4 days (Figure 1), 40\% of wounds showed complete wound closure in the $I L-12 / I L$ $23 p 40^{-/-}$mice, compared with only $10 \%$ in the WT counterparts. By 7 days after wounding, some $90 \%$ of wounds in the $I L-12 / I L-23 p 40^{-/-}$mice had healed, compared with only $40 \%$ in the WT mice. By 10 days, all wounds in the $\mathrm{KO}$ mice showed an intact epithelial layer over the wound bed, while in the wildtype mice 1 of the 10 mice still had yet to establish complete epithelial cover at the same time point.

\section{Early inflammatory response cell infiltrate in knock-out mice}

The nature of the cellular infiltrate in the healing wounds was assessed using flow cytometry using markers for macrophages, neutrophils and CD31 positive cells (Figure 2). More infiltrating neutrophils were detected 1 day after wounding in the $\mathrm{KO}$ mice, however the increase did not reach statistical significance. $\mathrm{KO}$ mice displayed an increase in macrophage numbers from 0 to 7 days after injury, with almost double at 1 day after wounding compared to WT mice (11\% vs. $6.6 \%$, respectively). There

Table 1 Percentage of complete wound closure in IL-12/ $23 \mathrm{p} 40^{-/-}$and C57BL/6J mice.

\begin{tabular}{lcccc}
\hline Time after wounding & Day 1 & Day 4 & Day 7 & Day 10 \\
\hline IL-12/23p40 & $0 \%$ & $40 \% * *$ & $90 \% * *$ & $100 \%$ \\
\hline C57BL/6J & $0 \%$ & $10 \%$ & $40 \%$ & $80 \%$ \\
\hline
\end{tabular}

Wounds from the IL-12/23p $40^{-/-}$mice healed significantly faster at days 4 and 7 compared to C57BL/6J control mice. Log-rank (Mantel-Cox) Test, $p=0.002^{* *}$; $\mathrm{n}=10$ per strain, per time point. 


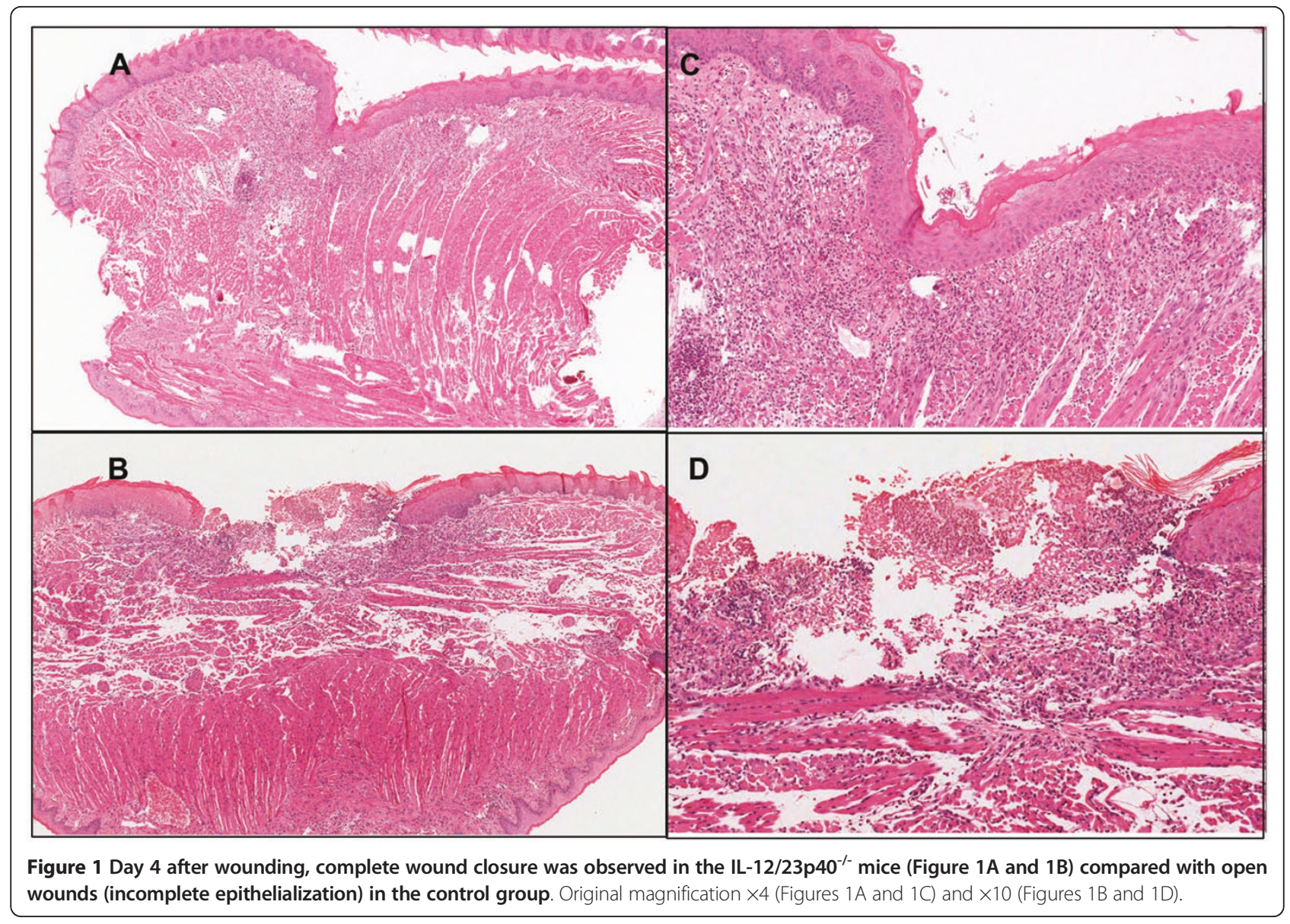

was a small increase in CD31 positive cells at day 1 in the KO mice, but this decreased to baseline levels by day 7 . An opposite trend was seen in the WT counterparts, where the number of CD31 positive cells increased from day 1 to day 7 after wounding. Overall there was a consistent trend for higher numbers of neutrophils, macrophages and CD31 positive cells in $\mathrm{KO}$ wounds.

Analysis of the neutrophil and macrophage infiltrate in the wounds using immunohistochemistry confirmed the trend of a greater inflammatory infiltrate in the $\mathrm{KO}$ mice There was a trend for more infiltrating neutrophils in $\mathrm{KO}$ mice 1 day after wounding compared to wildtype mice with the reverse trend at 4 days after wounding. Likewise, there was a trend for more infiltrating macrophages at days 0,1 and 4 in the $\mathrm{KO}$ mice compared with controls, which was in keeping with the flow cytometry data.

\section{Early upregulation mRNA of inflammatory and immune markers}

The summary of fold changes of all genes studied is provided in additional file 1 , table S1. Genes of interest are shown in Table 2. There were significant increased levels (more than 2 fold increase, $p<0.05$ ) within 24 hours after wounding in $I L-12 / I L-23 p 40^{-/-}$mice for the chemokines; endothelial derived neutrophil attractant (ENA78), macrophage inflammatory protein-2 alpha (MIP-2 $\alpha$ ), monocyte chemoattractant protein (MCP)-1 and MCP-3. MCP-1 and MCP-3 mRNA induction occurred from day 1 after wounding and peaked at day 4. The early induction of these chemokines was followed by reduction to baseline levels by day 7 . In addition, the pro-inflammatory cytokines IL- $1 \beta$ and IL- 6 showed a marked increase 1 day after wounding in $\mathrm{KO}$ mice, with fold increases of $953 \times$ and $247 \times$ respectively, compared to $165 \times$ and $20 \times$ in the WT counterparts (Table 2). This rapid increase was followed by an equally rapid return to baseline levels by day 4 . Overall, the data support an early inflammatory response to wounding in the KO mice compared to WT mice.

\section{Early establishment of angiogenesis in IL-12/IL-23p40 ${ }^{-/-}$ mice}

Anti-CD31 antibody was used to estimate the extent of angiogenesis. A significantly larger area of vascularization over the wound bed was demonstrated in $\mathrm{KO}$ mice 

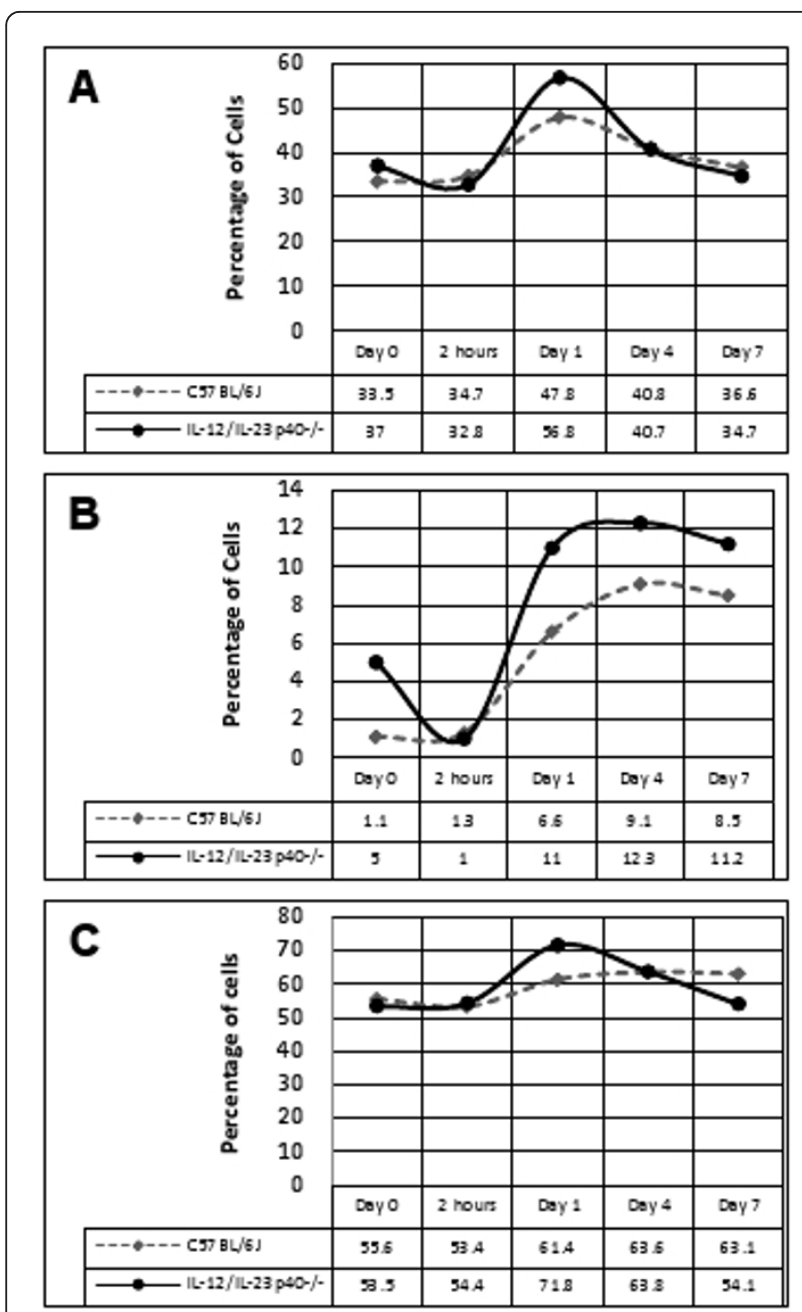

Figure 2 Percentage of neutrophils (A), macrophages (B) and CD31 positive cells $(C)$ detected in healing wounds of IL-12/IL$23 \mathrm{p}^{2 /-} 0^{-1}$ mice compared with C57BL/6J per 10,000 events.

at day 1 compared to WT mice $(55.3 \pm 6.7$ vs. $27.3 \pm$ 4.6; $p=0.026$ ) (Figure 3). Anti-Factor VIII was used to confirm areas of angiogenesis. The results from Factor VIII immunostaining were consistent with those for CD31,

with a greater area of staining at day 1 in the $\mathrm{KO}$ mice than in the WT mice $(25.3 \pm 3.0$ vs. $9.7 \pm 1.2$; $p=$ 0.008) (Figure 4). These two observations complemented the up-regulation of mRNA levels for VEGF-A in the $\mathrm{KO}$ group which was seen 2 hours after wounding compared to the WT mice. By 7 days after wounding, VEGF-A levels in the KO mice had returned to baseline, but they remained elevated in the WT mice $(p<0.05)$ (Figure 5A).

Cell counts for CD31 showed a larger infiltrate at day 1 in the KO mice compared to the WT mice (Figure $5 \mathrm{~B})$. There was a statistically significant difference in
Table 2 Fold changes of genes of interest during the time-course of a healing wound in IL-12/23p $40^{-/-}$and C57BL/6J mice.

\begin{tabular}{|c|c|c|c|c|}
\hline \multirow[t]{2}{*}{ Gene of Interest } & \multirow[t]{2}{*}{ Strain of Mouse } & \multicolumn{3}{|c|}{ Fold-Change } \\
\hline & & Day 1 & Day 4 & Day 7 \\
\hline & IL-12/IL-23p40 & 71.59 & 9.62 & 7.92 \\
\hline \multirow[t]{2}{*}{ MCP-1 } & C57BL/6J & 27.21 & 6.02 & 5.16 \\
\hline & IL-12/IL-23p40 & 128.6 & 17.63 & 11.77 \\
\hline \multirow[t]{2}{*}{ MCP-3 } & C57BL/6J & 58.07 & 8.76 & 8.55 \\
\hline & IL-12/IL-23p40 & 11235 & 788.3 & 1104 \\
\hline \multirow[t]{2}{*}{ MIP-2 } & C57BL/6J & 2073 & 763.9 & 274.5 \\
\hline & IL-12/IL-23p40 & 3028 & 1296 & 1523 \\
\hline \multirow[t]{2}{*}{ ENA-78 } & C57BL/6J & 974.4 & 2037 & 821.8 \\
\hline & IL-12/IL-23p40 & 953.9 & 86.42 & 215.6 \\
\hline \multirow[t]{2}{*}{ IL-1 $\beta$} & C57BL/6J & 165.0 & 115.7 & 59.11 \\
\hline & IL-12/IL-23p40 & 247.1 & 24.59 & 14.54 \\
\hline IL-6 & C57BL/6J & 20.84 & 35.77 & 13.76 \\
\hline
\end{tabular}

Expression profile of chemokines (MCP-1, MCP-3, MIP-2 and ENA-78) and cytokines (IL-1 $\beta$ and IL-6) seen in the IL-12/IL-23p $40^{-/-}$mice parallel the early recruitment of inflammatory cells and early establishment of an inflammatory response. Fold-changes were calculated using $\mathrm{C} 57 \mathrm{BL} / 6 \mathrm{~J}$ unwounded samples as control group. Student's t-test, $p$ value $<0.05 ; \mathrm{n}=2$ per strain, per time point.

CD31 positive stained cells 4 days after wounding. The control group had an increasingly larger infiltrate, while there was a decreased number of $\mathrm{CD} 31^{+}$cell infiltrate in the KO group $(p=0.002)$. This observation between the two strains of mice at the same time point was clearly visible at the base of the wounds, adjacent to the wound edges. In the $\mathrm{KO}$ mice, the base of the wound displayed a more organized granulation tissue compartment compared to the WT mice where numerous blood vessels are scattered around a largely unorganized matrix compartment.

\section{Discussion}

Research into wound healing can help decipher the intricate molecular and cellular mechanisms involved in repair, and can also provide clues to novel therapeutic targets for promoting regenerative healing. This preliminary study investigated the effect of deficiency of IL12 and IL-23 in wound healing using cytokine $\mathrm{KO}$ mice. This study is the first to demonstrate that $I L-12 / I L$ $23 p 40^{-/-}$mice display significant acceleration of healing of oral mucosal wounds compared to controls. The accelerated wound closure likely occurs through multiple mechanisms. Firstly, there is a small influence on neutrophil infiltration at day 1 after wounding in the $\mathrm{KO}$ mice but is likely to be of lesser importance than the enhanced influx of macrophages which follows it. IL- $12 / \mathrm{IL}-23$ p 40 is produced by both neutrophils and macrophages as well as by other inflammatory cells, and 


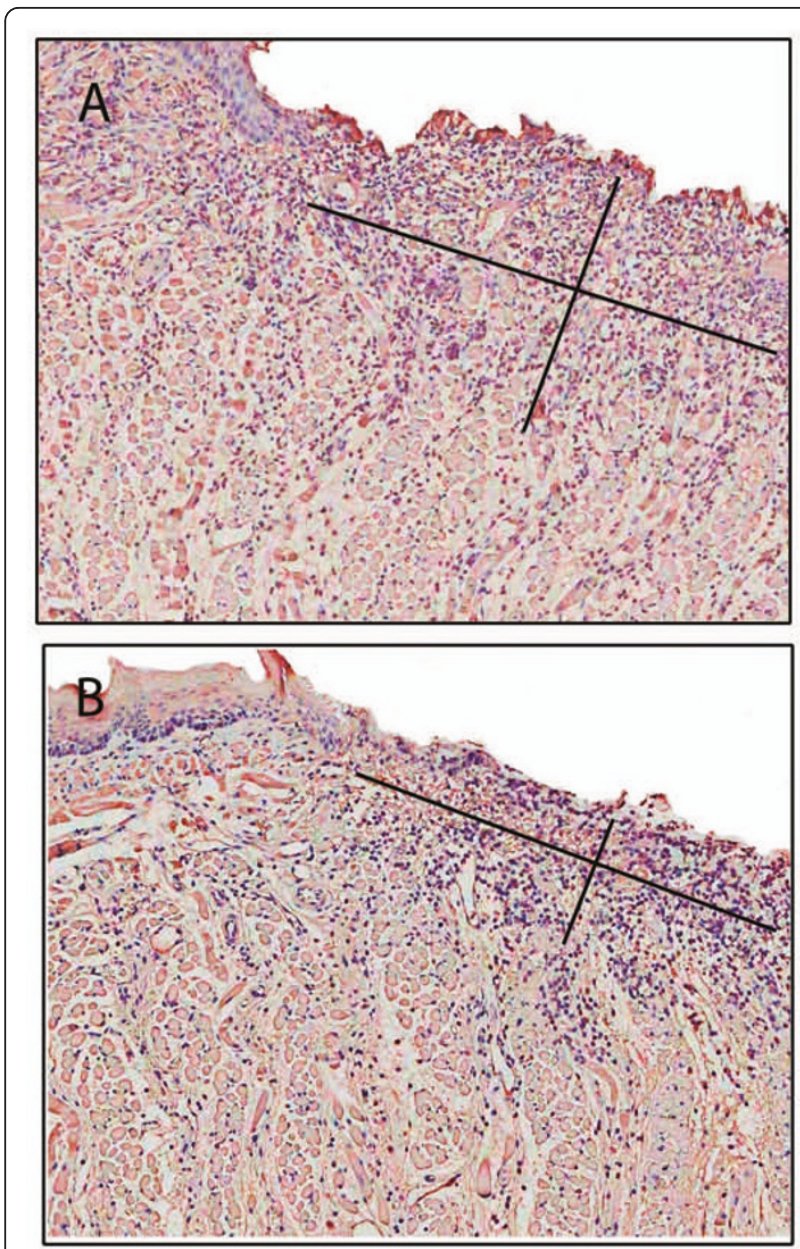

Figure 3 Analysis of angiogenesis at wound sites. Sections were stained with anti-CD31 antibody. Immunohistochemical sections 1 day after wounding in IL-12/IL-23p40 ${ }^{-/-}$mice (A) and C57BL/6J (B). The area of $\mathrm{CD}_{3} 1^{+}$site was significantly larger in the $\mathrm{KO}$ group compared to control group 1 day after wounding (55.3 \pm 6.7 vs. $27.3 \pm 4.6 ; p=0.026$ ). The diagonal cross overlaid on the slide image shows approximately areas of $\mathrm{CD}_{3} 1^{+}$sites.

is a known chemoattractant for macrophages, however its effects are less potent than other macrophage chemoattractants such as MIP-1, MCP-1 and RANTES [27-29]. Because of redundancy, the absence of the IL12/IL-23p40 molecule in KO mice may elicit a greater compensatory response from other pathways which enhance the recruitment of macrophages. Together, the increased infiltration of neutrophils and macrophages appears to have a favorable effect on the progression of the healing process.

Preliminary analysis of mRNA levels of chemokines which are chemoattractants for neutrophils and macrophages partially explains the trend for a larger inflammatory infiltrate in the KO group. Both GRO-1 and ENA-78 are released by degranulating platelets and initiate neutrophil recruitment into the wound bed [30-32]. The early induction of these chemokines after wounding in IL-12/IL-23p40 KO mice would enhance neutrophil influx. Likewise, enhanced expression of MIP-3a and MDC may also contribute to earlier recruitment of macrophages in the KO mice. MIP-3a and MDC mediated recruitment of macrophages augments the inflammatory response and promotes debridement during wound healing $[27,33]$. In addition, the chemokines GRO-1, MIP-2 and ENA-78 mediate angiogenesis and epithelialization [33,34]. Early induction of such chemokines would create an environment conducive to accelerated epithelialization and formation of capillaries in the healing wound.

Polymorphonuclear leukocytes and macrophages as well as some resident fibroblasts and keratinocytes secrete IL- $1 \beta$ and IL- 6 in a healing wound, and mRNA expression of these cytokines is up-regulated during the inflammatory phase of healing [35-37]. Both IL-1 $\beta$ and IL- 6 showed rapid and marked increase within 1 day of wounding in $\mathrm{KO}$ mice. IL-1 stimulates keratinocyte migration and proliferation, and enhances fibroblast secretion of fibroblast growth factor (FGF)-7 [32]. IL-6 is chemoattractive to neutrophils, and a potent mitogen for keratinocytes. The marked upregulation of IL-1 $\beta$ and IL-6 provides evidence of an early inflammatory response, but most importantly this was followed by rapid return to baseline levels which demonstrate a robust but controlled inflammatory response. The simultaneous presence of IL-6 and IL- 1 within 24 hours after wounding would increase neutrophil infiltration into the wound site and promote epithelial closure, and thereby contribute to accelerated healing [32].

Early induction of VEGF-A is a further mechanism which would be operating in $\mathrm{KO}$ mice. This growth factor promotes the early events in angiogenesis, particularly endothelial cell migration and proliferation [38-44], which in turn leads to the formation of granulation tissue. Angiogenesis is essential for effective healing, and inhibition of angiogenesis delays or impairs wound healing [45,46]. In the $I L-12 / I L-23 p 40^{-/-}$mice, angiogenesis was well established by the first day after wounding, as demonstrated by staining for CD31 and Factor VIII in tissue sections, and by analysis of cell homogenates for CD31 positive cells. The earlier establishment of an angiogenic response in the $\mathrm{KO}$ mice is implicated as a major mechanism which underpins accelerated wound healing.

As mentioned previously, the influence of IL-12 on angiogenesis is mediated through IFN- $\gamma$ [14], however recent findings support an alternative pathway. The presence of IL-12 has been associated with down-regulation of MMP-9 [15,47-49] which directly affects endothelial cell function and inhibits angiogenesis [49]. MMP-9 facilitates angiogenesis by breaking down the ECM, 

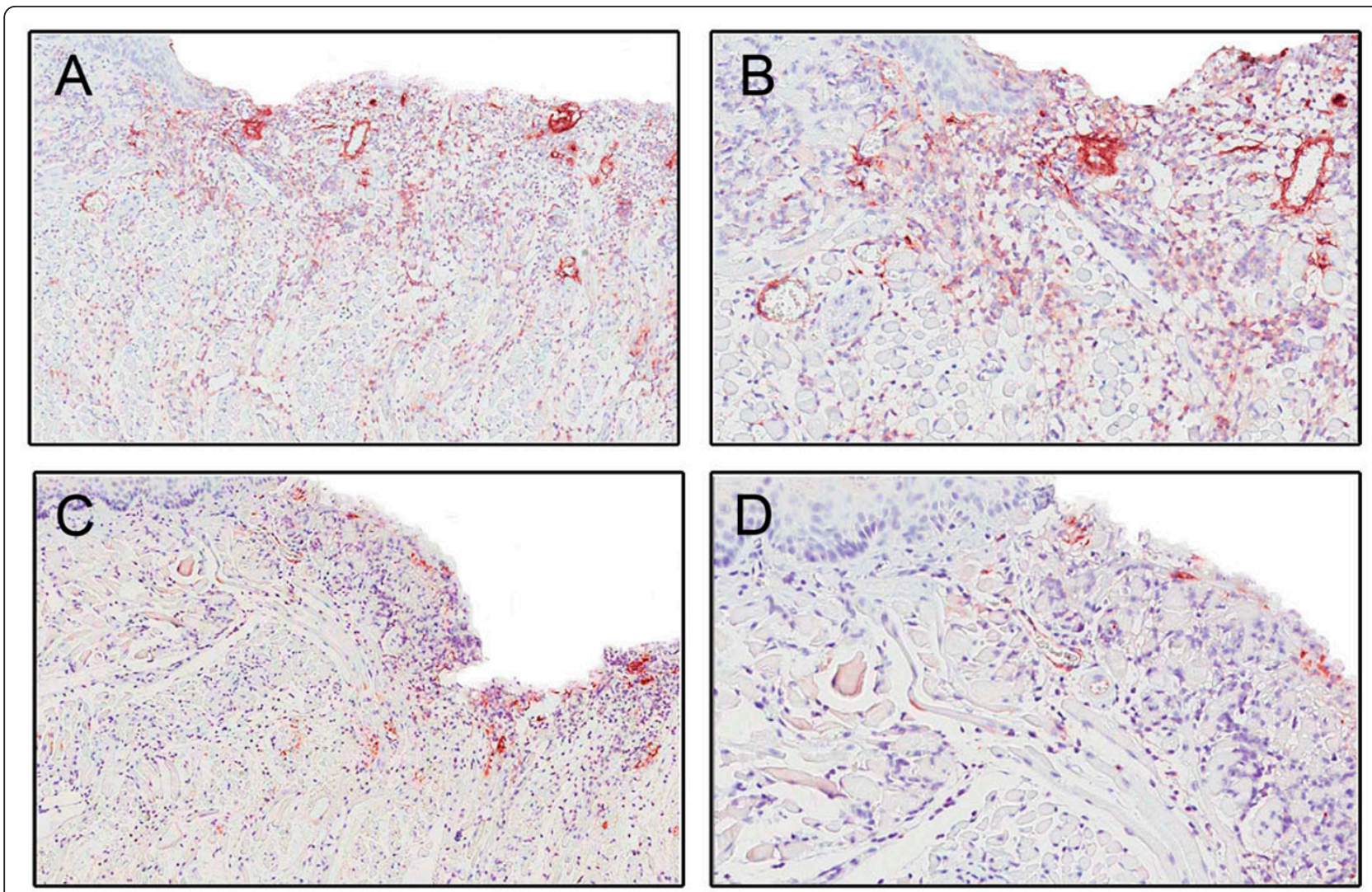

Figure 4 Analysis of angiogenesis at wound sites. Figures $4 \mathrm{~A}$ and $4 \mathrm{~B}$ show immunohistochemical sections 1 day after wounding in IL-12/IL$23 \mathrm{p} 40^{-1-}$ mice. Sections were stained with anti-Factor VIII. Original magnification $\times 4$ and $\times 20$, respectively. Figures $4 \mathrm{C}$ and $4 \mathrm{D}$ show sections of C57BL/6J wounds 1 day after wounding (stained with anti-Factor VIII). Original magnification $\times 4$ and $\times 20$, respectively. There was a significantly larger Factor VIII positive area in the knockout mice compared to wild-type controls (t-test; $p$ value 0.008).

allowing endothelial cells to migrate, proliferate and differentiate into new capillaries [50]. Additionally, MMP-9 may further support this process by releasing matrixsequestrated angiogenic growth factors, such as PDGF [51]. Recently, evidence of a direct link between MMP-9 and VEGF-induced angiogenesis has also been demonstrated [52]. The findings from this study infer that deficiency of IL-12 appears to be influential in facilitating the establishment of an early angiogenic response to wounding. Whether this effect is mediated through IFN$\gamma$ or through the downstream effect of MMP-9 on angiogenesis is yet to be determined. Nevertheless, the reciprocal relationship between IL-12, MMP-9 and VEGF warrants further investigation in light of new findings in this study.

Taken together, the expression profiles for chemokines and cytokines in this preliminary analysis in IL-12/IL$23 \mathrm{p} 40^{-/-}$mice parallel the key events of early recruitment of phagocytes, enhanced epithelialization, and early establishment of angiogenesis which together contribute to the favorable healing phenotype observed. The next aspect of this study would involve further investigation and confirmation of causal roles of mediators identified including specific chemokines, as well as facilitators of angiogenesis. In addition, experiments including single $\mathrm{KO}$ mice lacking only IL-12 or IL-23 would be used to distinguish the contribution of this distinct cytokines to the accelerated healing phenotype observed in this study. Apart from using these mediators as potential novel therapeutic agents of repair, this study also provides a platform to investigate related chronic conditions such as impaired healing in diabetics, as well as cutaneous conditions such as psoriasis. The relationship of IL-12 and IL-23 is of particular interest in light of recent publications that have reported IL-12p40 polymorphism affecting age of onset and deterioration of glycemic control in certain racial groups [53,54]. Apart from this genetic link between diabetes and IL-12/IL$23 p 40$, immunological studies have demonstrated that therapies enhancing BTLA-negative co-signalling may be a potential therapeutic target in treating autoimmune diabetes [55]. Moreover, genetic variations that encode subunits of cytokines (IL-12B, IL-23A) or cytokine receptors (IL-23R) have been associated with immune disorders such as psoriasis and psoriatic co-morbidities, including 


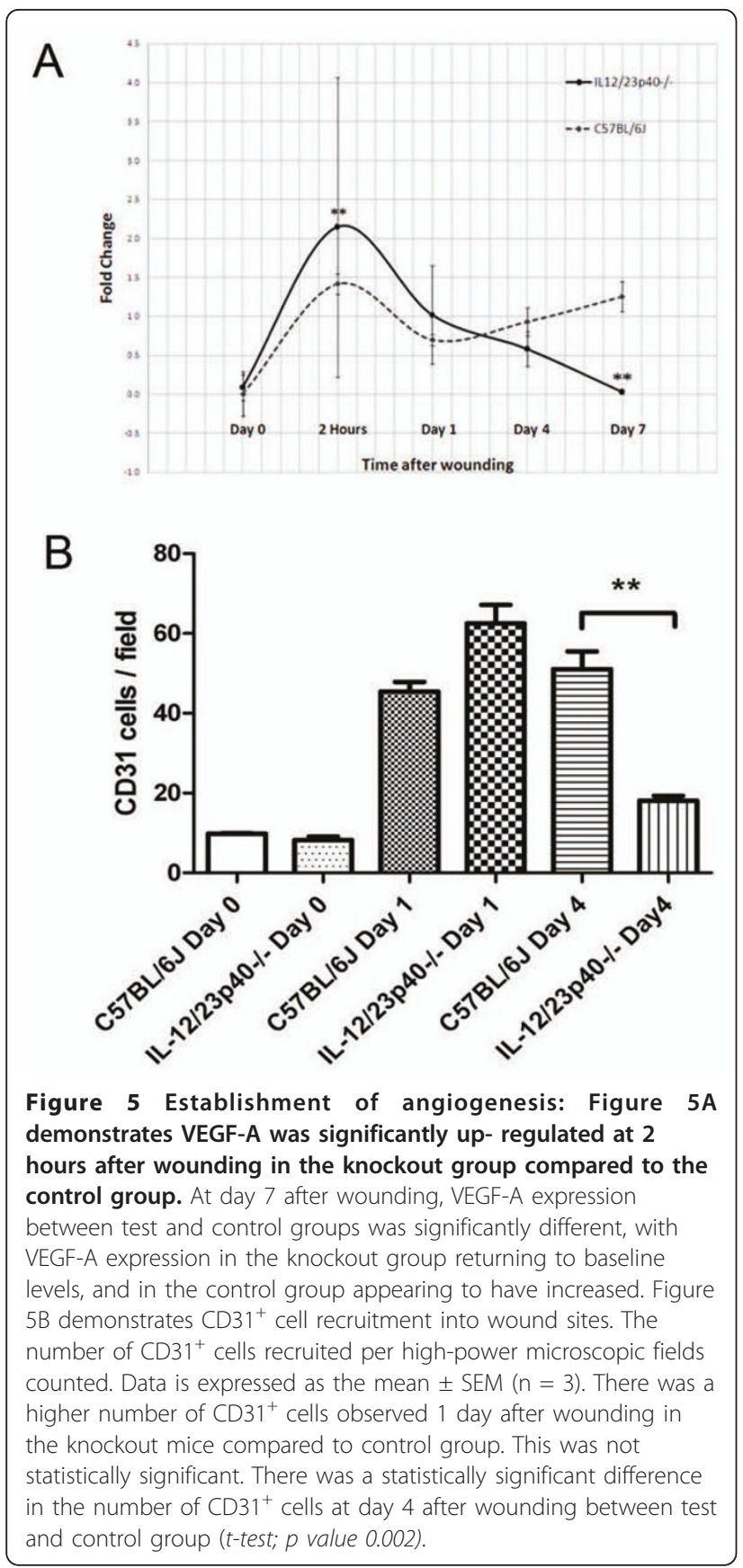

Crohn's disease and diabetes[56]. In summary, there is great scope in exploring the impact of IL-12/IL-23p40 and wound healing and its relation to several chronic diseases.

\section{Additional material}

Additional file 1: Table S1 - Summary of fold changes in mRNA of genes of interest. This file contains the summary of fold changes in mRNA of all genes of interest studied. The fold changes upregulated $\geq 3$ fold are enumerated in green, fold changes downregulated $\geq 3$ are enumerated in red, while statistical significance $\leq 0.05$ is enumerated in blue.

\section{Acknowledgements}

This project was supported by the Australian Dental Research Foundation (ADRF). We thank Mr. Anthony Chan for technical support with histology.

\section{Author details}

'University of Queensland, School of Dentistry, Brisbane, Australia. ${ }^{2}$ University of Queensland, University of Queensland Centre for Clinical Research (UQCCR), Brisbane, Australia. ${ }^{3}$ Griffith University, School of Dentistry and Oral Health, Gold Coast, Australia.

\section{Authors' contributions}

MATM performed all experiments and drafted the manuscript. JMS participated in RNA extraction and flow cytometry methods. CSF provided animal samples. CSF, LWJ and SI participated in study design and manuscript writing. All authors read and approved the final manuscript.

\section{Competing interests}

The authors declare that they have no competing interests.

Received: 19 August 2011 Accepted: 20 December 2011 Published: 20 December 2011

\section{References}

1. Nwomeh BC, Liang HX, Cohen IK, Yager DR: MMP-8 is the predominant collagenase in healing wounds and nonhealing ulcers. J Surg Res 1999, 81:189-195.

2. Mast BA, Diegelmann RF, Krummel TM, Cohen IK: Scarless wound healing in the mammalian fetus. Surg Gynecol Obstet 1992, 174:441-451.

3. Martin P, D'Souza D, Martin J, Grose R, Cooper L, Maki R, McKercher SR: Wound healing in the PU.1 null mouse-tissue repair is not dependent on inflammatory cells. Curr Biol 2003, 13:1122-1128.

4. Cooper L, Johnson C, Burslem F, Martin P, Cooper L, Johnson C, Burslem F, Martin $P$ : Wound healing and inflammation genes revealed by array analysis of 'macrophageless' PU.1 null mice. Genome Biol 2005, 6:R5.

5. Gallucci RM, Simeonova PP, Matheson JM, Kommineni C, Guriel JL, Sugawara T, Luster MI: Impaired cutaneous wound healing in interleukin6-deficient and immunosuppressed mice. Faseb J 2000, 14:2525-2531.

6. Ishida Y, Kondo T, Kimura A, Matsushima K, Mukaida N: Absence of IL-1 receptor antagonist impaired wound healing along with aberrant NFkappaB activation and a reciprocal suppression of TGF-beta signal pathway. J Immunol 2006, 176:5598-5606.

7. Mori R, Kondo T, Ohshima T, Ishida Y, Mukaida N: Accelerated wound healing in tumor necrosis factor receptor p55-deficient mice with reduced leukocyte infiltration. Faseb J 2002, 16:963-974.

8. Ishida Y, Kondo T, Takayasu T, Iwakura Y, Mukaida N, Ishida Y, Kondo T, Takayasu T, Iwakura Y, Mukaida N: The essential involvement of cross-talk between IFN-gamma and TGF-beta in the skin wound-healing process. J Immunol 2004, 172:1848-1855.

9. Eming SA, Werner S, Bugnon P, Wickenhauser C, Siewe L, hlen O, Davidson JM, Krieg T, et al: Accelerated wound closure in mice deficient for interleukin-10. Am J Pathol 2007, 170:188-202.

10. Muller G, Saloga J, Germann T, Bellinghausen I, Mohamadzadeh M, Knop J, Enk AH: Identification and induction of human keratinocyte-derived IL12. J Clin Invest 1994, 94:1799-1805.

11. Trinchieri G, Pflanz S, Kastelein RA, Trinchieri G, Pflanz S, Kastelein RA: The IL-12 family of heterodimeric cytokines: new players in the regulation of T cell responses. Immunity 2003, 19:641-644.

12. Mikols CL, Yan L, Norris JY, Russell TD, Khalifah AP, Hachem RR, Chakinala MM, Yusen RD, Castro M, Kuo E, et al: IL-12 p80 is an innate epithelial cell effector that mediates chronic allograft dysfunction. Am J Respir Crit Care Med 2006, 174:461-470.

13. Saunus JM, Wagner SA, Matias MA, Hu Y, Zaini ZM, Farah CS: Early activation of the interleukin-23-17 axis in a murine model of oropharyngeal candidiasis. Molec Oral Microb 2010, 25:343-356.

14. Voest EE, Kenyon BM, O'Reilly MS, Truitt G, D'Amato RJ, Folkman J: Inhibition of angiogenesis in vivo by interleukin 12. J Natl Cancer Inst 1995, 87:581-586.

15. Meeran SM, Katiyar S, Elmets CA, Katiyar SK, Meeran SM, Katiyar S, Elmets CA, Katiyar SK: Interleukin-12 deficiency is permissive for angiogenesis in UV radiation-induced skin tumors. Cancer Res 2007 . 67:3785-3793. 
16. Luster AD, Cardiff RD, MacLean JA, Crowe K, Granstein RD: Delayed wound healing and disorganized neovascularization in transgenic mice expressing the IP-10 chemokine. Proc Assoc Am Physicians 1998, 110:183-196.

17. Luster AD, Greenberg SM, Leder P: The IP-10 chemokine binds to a specific cell surface heparan sulfate site shared with platelet factor 4 and inhibits endothelial cell proliferation. J Exp Med 1995, 182:219-231.

18. Gillessen S, Carvajal D, Ling P, Podlaski FJ, Stremlo DL, Familletti PC, Gubler U, Presky DH, Stern AS, Gately MK: Mouse interleukin-12 (IL-12) p40 homodimer: a potent IL-12 antagonist. Eur J Immunol 1995, 25:200-206.

19. Ling P, Gately MK, Gubler U, Stern AS, Lin P, Hollfelder K, Su C, Pan YC, Hakimi J: Human IL-12 p40 homodimer binds to the IL-12 receptor but does not mediate biologic activity. J Immunol 1995, 154:116-127.

20. Ha SJ, Lee CH, Lee SB, Kim CM, Jang KL, Shin HS, Sung YC: A novel function of IL-12p40 as a chemotactic molecule for macrophages. $J$ Immunol 1999, 163:2902-2908.

21. Khader SA, Partida-Sanchez S, Bell G, Jelley-Gibbs DM, Swain S, Pearl JE, Ghilardi N, Desauvage FJ, Lund FE, Cooper AM, et al: Interleukin 12p40 is required for dendritic cell migration and $\mathrm{T}$ cell priming after Mycobacterium tuberculosis infection. J Exp Med 2006, 203:1805-1815.

22. Langowski JL, Zhang X, Wu L, Mattson JD, Chen T, Smith K, Basham B, McClanahan T, Kastelein RA, Oft M, et al: IL-23 promotes tumour incidence and growth. Nature 2006, 442:461-465.

23. Magram J, Connaughton SE, Warrier RR, Carvajal DM, Wu CY, Ferrante J, Stewart C, Sarmiento U, Faherty DA, Gately MK: IL-12-deficient mice are defective in IFN gamma production and type 1 cytokine responses. Immunity 1996, 4:471-481.

24. Harper EG, Guo C, Rizzo H, Lillis JV, Kurtz SE, Skorcheva I, Purdy D, Fitch E, lordanov M, Blauvelt A: Th17 cytokines stimulate CCL20 expression in keratinocytes in vitro and in vivo: implications for psoriasis pathogenesis. J Invest Derm 2009, 129:2175-2183.

25. Low QE, Drugea IA, Duffner LA, Quinn DG, Cook DN, Rollins BJ, Kovacs EJ, DiPietro LA: Wound healing in MIP-1alpha(-/-) and MCP-1(-/-) mice. Am J Pathol 2001, 159:457-463.

26. Ishida Y, Kondo T, Takayasu T, Iwakura Y, Mukaida N: The essential involvement of cross-talk between IFN-gamma and TGF-beta in the skin wound-healing process. J Immunol 2004, 172:1848-1855.

27. DiPietro LA, Burdick M, Low QE, Kunkel SL, Strieter RM: MIP-1alpha as a critical macrophage chemoattractant in murine wound repair. J Clin Invest 1998, 101:1693-1698.

28. Frank S, Kampfer H, Wetzler C, Stallmeyer B, Pfeilschifter J: Large induction of the chemotactic cytokine RANTES during cutaneous wound repair: a regulatory role for nitric oxide in keratinocyte-derived RANTES expression. Biochem J 2000, , 347 Pt 1:: 265-273.

29. Wetzler C, mpfer H, Stallmeyer B, Pfeilschifter J, Frank S: Large and sustained induction of chemokines during impaired wound healing in the genetically diabetic mouse: prolonged persistence of neutrophils and macrophages during the late phase of repair. J Invest Derm 2000, 115:245-253.

30. Gillitzer R: Inflammation in human skin: a model to study chemokinemediated leukocyte migration in vivo. J Pathol 2001, 194:393-394.

31. Gillitzer R, Goebeler M: Chemokines in cutaneous wound healing. J Leukoc Biol 2001, 69:513-521.

32. Werner $S$, Grose R: Regulation of wound healing by growth factors and cytokines. Physiol Rev 2003, 83:835-870.

33. Engelhardt E, Toksoy A, Goebeler M, Debus S, Brocker EB, Gillitzer R: Chemokines IL-8, GROalpha, MCP-1, IP-10, and Mig are sequentially and differentially expressed during phase-specific infiltration of leukocyte subsets in human wound healing. Am J Pathol 1998, 153:1849-1860.

34. Romagnani P, Lasagni L, Annunziato F, Serio M, Romagnani S: CXC chemokines: the regulatory link between inflammation and angiogenesis. Trends Immunol 2004, 25:201-209.

35. Grellner W, Georg T, Wilske J: Quantitative analysis of proinflammatory cytokines (IL-1beta, IL-6, TNF-alpha) in human skin wounds. Forensic Sci Int 2000, 113:251-264.

36. Grose R, Harris BS, Cooper L, Topilko P, Martin P: Immediate early genes krox-24 and krox-20 are rapidly up-regulated after wounding in the embryonic and adult mouse. Dev Dyn 2002, 223:371-378.

37. Hubner G, Brauchle M, Smola H, Madlener M, Fassler R, Werner S: Differential regulation of pro-inflammatory cytokines during wound healing in normal and glucocorticoid-treated mice. Cytokine 1996 8:548-556.

38. Yebra M, Parry GC, mblad S, Mackman N, Rosenberg S, Mueller BM, Cheresh DA: Requirement of receptor-bound urokinase-type plasminogen activator for integrin alphavbeta5-directed cell migration. J Biol Chem 1996, 271:29393-29399

39. Suzuma K, Takagi H, Otani A, Honda Y: Hypoxia and vascular endothelial growth factor stimulate angiogenic integrin expression in bovine retinal microvascular endothelial cells. Invest Ophthalmol Vis Sci 1998, 39:1028-1035.

40. Senger DR, Ledbetter SR, Claffey KP, Papadopoulos-Sergiou A, Peruzzi CA, Detmar M: Stimulation of endothelial cell migration by vascular permeability factor/vascular endothelial growth factor through cooperative mechanisms involving the alphavbeta3 integrin, osteopontin, and thrombin. Am J Pathol 1996, 149:293-305.

41. Morbidelli L, Chang CH, Douglas JG, Granger HJ, Ledda F, Ziche M: Nitric oxide mediates mitogenic effect of VEGF on coronary venular endothelium. Am J Physiol 1996, 270:H411-415.

42. Pepper MS, Ferrara N, Orci L, Montesano R: Potent synergism between vascular endothelial growth factor and basic fibroblast growth factor in the induction of angiogenesis in vitro. Biochem Biophys Res Commun 1992, 189:824-831.

43. Goto F, Goto K, Weindel K, Folkman J: Synergistic effects of vascular endothelial growth factor and basic fibroblast growth factor on the proliferation and cord formation of bovine capillary endothelial cells within collagen gels. Lab Invest 1993, 69:508-517.

44. Watanabe $Y$, Lee SW, Detmar M, Ajioka I, Dvorak HF: Vascular permeability factor/vascular endothelial growth factor (VPF/VEGF) delays and induces escape from senescence in human dermal microvascular endothelial cells. Oncogene 1997, 14:2025-2032.

45. Roman CD, Choy H, Nanney L, Riordan C, Parman K, Johnson D Beauchamp RD: Vascular endothelial growth factor-mediated angiogenesis inhibition and postoperative wound healing in rats. J Surg Res 2002, 105:43-47.

46. McGrath MH, Emery JM: The effect of inhibition of angiogenesis in granulation tissue on wound healing and the fibroblast. Ann Plast Surg 1985, 15:105-122.

47. Dias S, Boyd R, Balkwill F: IL-12 regulates VEGF and MMPs in a murine breast cancer model. Int J Cancer 1998, 78:361-365.

48. Mitola S, Strasly M, Prato M, Ghia P, Bussolino F: IL-12 regulates an endothelial cell-lymphocyte network: effect on metalloproteinase-9 production. J Immunol 2003, 171:3725-3733.

49. Strasly M, Cavallo F, Geuna M, Mitola S, Colombo MP, Forni G, Bussolino F: IL-12 inhibition of endothelial cell functions and angiogenesis depends on lymphocyte-endothelial cell cross-talk. J Immunol 2001, 166:3890-3899.

50. Stupack DG, Cheresh DA: ECM remodeling regulates angiogenesis: endothelial integrins look for new ligands. [Review] [69 refs]. Science's Stke [Electronic Resource]: Signal Transduction Knowledge Environment 2002, 2002:PE7.

51. Bergsten E, Uutela M, Li X, Pietras K, Ostman A, Heldin CH, Alitalo K, Eriksson U: PDGF-D is a specific, protease-activated ligand for the PDGF beta-receptor. Nat Cell Biol 2001, 3:512-516.

52. Hao Q, Su H, Palmer D, Sun B, Gao P, Yang G-Y, Young WL: Bone marrowderived cells contribute to vascular endothelial growth factor-induced angiogenesis in the adult mouse brain by supplying matrix metalloproteinase-9. Stroke 2011, 42:453-458.

53. Altinova AE, Engin D, Akbay E, Akturk M, Toruner F, Ersoy R, Yetkin I, Arslan M: Association of polymorphisms in the IL-18 and IL-12 genes with susceptibility to Type 1 diabetes in Turkish patients. J Endocrinol Invest 2010, 33:451-454

54. Morahan G, McKinnon E, Berry J, Browning B, Julier C, Pociot F, James I, Type IDGC: Evaluation of IL12B as a candidate type I diabetes susceptibility gene using data from the Type I Diabetes Genetics Consortium. Genes Immun 2009, 10(Suppl 1):S64-68.

55. Truong W, Hancock WW, Plester JC, Merani S, Rayner DC, Thangavelu G, Murphy KM, Anderson CC, Shapiro AMJ: BTLA targeting modulates lymphocyte phenotype, function, and numbers and attenuates disease in nonobese diabetic mice. J Leukoc Biol 2009, 86:41-51. 
56. Duffin KC, Woodcock J, Krueger GG: Genetic variations associated with psoriasis and psoriatic arthritis found by genome-wide association. Dermatol Therapy 2010, 23:101-113.

doi:10.1186/1476-9255-8-39

Cite this article as: Matias et al: Accelerated wound healing phenotype in Interleukin 12/23 deficient mice. Journal of Inflammation 2011 8:39.

Submit your next manuscript to BioMed Central and take full advantage of:

- Convenient online submission

- Thorough peer review

- No space constraints or color figure charges

- Immediate publication on acceptance

- Inclusion in PubMed, CAS, Scopus and Google Scholar

- Research which is freely available for redistribution 